Jurnal Ilmu Dan Teknologi Kesehatan

Vol 7, No 2, Maret 2020,

ISSN: 2338-9095 (Print)

ISSN: 2338-9109 (online)

\title{
Perception of Prevention Stunting Through Healthy Lifestyle in Adolescent Girls: Case Study of Adolescents in Bantul, Yogyakarta
}

\author{
Dina Fitriana Rosyada, Marko Ferdian Salim, M. Syairaji \\ Sekolah Vokasi, Universitas Gadjah Mada \\ Email:dinafitriana.r@ugm.ac.id
}

\author{
Article history \\ Posted, Jan 29th, 2020 \\ Reviewed, Feb 25th, 2020 \\ Received, March 10th, 2020
}

\begin{abstract}
Stunting is one of the targets of sustainable development goals (SDGs) included in the second sustainable development goal of eliminating hunger and all forms of malnutrition by 2030 and achieving food security. Indonesia is included in the third country with the highest stunting prevalence in the south-east Asia region (sear). One of the regions in java where there are stunting cases is in Yogyakarta, namely in Bantul Regency. This research aims to determine the perception of young women about stunting prevention through healthy living. This research is qualitative research with a case study approach. The variable in this study is the perception of young women regarding the prevention of stunting through a healthy lifestyle. This research concluded that some female subjects already understood the definition of stunting but did not yet know the important role of adolescents in the prevention of stunting before pregnancy. This shows that there is no appropriate perception among adolescents regarding the prevention of stunting with a healthy lifestyle since early adolescence. If the adolescent is not repaired, so in the future, there will be more and more expectant mothers who have short body posture and/or lack of chronic energy.
\end{abstract}

Keywords: stunting; perception; adolescent; prevention

\begin{abstract}
ABSTRAK
Stunting adalah salah satu target tujuan pembangunan berkelanjutan (SDGs) yang termasuk dalam tujuan pembangunan berkelanjutan kedua yaitu menghilangkan kelaparan dan segala bentuk kekurangan gizi pada tahun 2030 dan mencapai ketahanan pangan. Indonesia termasuk dalam negara ketiga dengan prevalensi stunting tertinggi di wilayah Asia Tenggara. Salah satu daerah di Jawa yang memiliki kasus stunting adalah di Yogyakarta, yaitu di Kabupaten Bantul. Penelitian ini bertujuan untuk mengetahui persepsi remaja putri tentang pencegahan stunting melalui hidup sehat. Penelitian ini adalah penelitian kualitatif dengan pendekatan studi kasus. Variabel dalam penelitian ini adalah persepsi remaja tentang pencegahan stunting melalui gaya hidup sehat. Dari penelitian ini disimpulkan bahwa beberapa subjek sudah memahami definisi stunting tetapi belum mengetahui peran penting remaja dalam pencegahan stunting sebelum kehamilan. Hal ini menunjukkan bahwa tidak ada persepsi yang tepat di kalangan remaja mengenai pencegahan stunting dengan gaya hidup
\end{abstract}


sehat sejak remaja awal. Jika seperti itu maka di masa depan, akan ada lebih banyak ibu hamil yang memiliki postur tubuh pendek dan atau kekurangan energi kronis.

Kata kunci: stunting; persepsi; remaja; pencegahan

\section{INTRODUCTION}

Short toddlers or so-called stunting is one of the nutritional problems experienced by toddlers in the world today. Stunting is a disorder of growth and development experienced by children from malnutrition, recurrent infections, and inadequate psychosocial stimulation. Children are defined as being stunted if their height is more than two standard deviations below the median of child growth standards (WHO, 2019). In 2017, 22.2\% or around 150.8 million children under five in the world experienced stunting. More than half of stunted children under five in the world come from Asia (55\%), while more than one third (39\%) live in Africa (WHO, Joint child malnutrition estimates, 2018). Stunting prevalence data collected by the World Health Organization (WHO), Indonesia is included in the third country with the highest prevalence in the SouthEast Asia Region (SEAR). The average incidence of stunting toddlers in Indonesia in 2018 is $36.4 \%$ (World Health Statistics data visualizations dashboard, 2019).

Linear growth in early childhood is a reliable marker of healthy growth given its relationship with morbidity and mortality risks, non-communicable diseases later in life, and learning capacity and productivity. It is also closely related to child development in several domains, including cognitive, language, and sensory-motor capacity. Stunting cases in Indonesia occur more outside Java, such as in East Nusa Tenggara, Papua, Sulawesi, and Maluku. However, this does not mean that there are no stunting cases in Java, although it is generally known that health service facilities are sufficient, where data also states that infants on Java have higher life expectancy than those outsides of Java (Buku Saku Pemantauan Status Gizi, 2017). One of the regions in Java where there are stunting cases is in Yogyakarta, namely in Bantul Regency. According to WHO, the prevalence of short children becomes a public health problem if the prevalence reaches $20 \%$ or more (Buletin Jendela Data dan Informasi Kesehatan, 2018). The incidence of stunting cases in Yogyakarta is $19.8 \%$. Even so, it does not mean the number of cases is not alarming (Dinas Kesehatan Daerah Istimewa Yogyakarta, 2018). 
On the other hand, data on early marriage rates in Yogyakarta have increased again due to various triggering factors, including the result of premarital sex among adolescents, premarital pregnancy, poverty, and culture. It is addressed by marrying adolescents as an act of gender control, namely efforts to control the role of women for family status and selfesteem. Girls are considered a burden, in addition to limited access to education and a lack of knowledge and understanding of sexual health and reproductive health both for adolescents and parents (RRI, 2019).

Stunting is one of the targets of Sustainable Development Goals (SDGs) included in the second sustainable development goal of eliminating hunger and all forms of malnutrition by 2030 and achieving food security. The target set is to reduce the stunting rate by $40 \%$ by 2025 . To realize this, the government has established stunting as one of the priority programs. Based on the Peraturan Menteri Kesehatan Republik Indonesia No. 39 of 2016 concerning Guidelines for the Implementation of the Healthy Indonesia Program with a Family Approach, efforts made to reduce the prevalence of stunting can be made based on vulnerable groups of people. One of which is prevention that can be done since adolescence, increasing counseling for clean living behavior and healthy (PHBS), balanced nutritional patterns, not smoking, not taking drugs, and providing reproductive health education. This study takes a theme related to adolescent perceptions associated with the prevention of stunting through healthy living by teenagers in Bantul Regency, Yogyakarta. It is expected that by knowing their opinions about stunting prevention through healthy living, efforts to prevent stunting programs can be carried out well so that stunting rates can continue to fall.

\section{METHOD}

This research is qualitative research with a case study approach. Qualitative research is research that emphasizes non-numerical analysis and interpretive analysis of social phenomena (Creswell, 2011; Sugiyono, 2014). Case studies are one type of qualitative research method in which researchers conduct in-depth exploration of programs, events, activities, processes, to one or more people. This type is bound by the time and activity of researchers that is conducting comprehensive data collection using various data collection procedures and in continuous time. This research was conducted on young women in Bantul Regency, Yogyakarta. The variable in this study is the perception of 
young women regarding the prevention of stunting through a healthy lifestyle.

The study was conducted in Bantul Regency, Yogyakarta. Subjects in this study were 12 young women aged 18 to 20 years and one nutritionist from Gadjah Mada Health Center (GMC). While the object of this research is perception related to the prevention of stunting cases. Data collection is done through in-depth interviews and literature studies. Interviews with young women were conducted to obtain data on perceptions of young women regarding stunting prevention through healthy living. Interviews with nutritionists were conducted to collect data on stunting prevention from the side of young women. A literature study is conducted to process data and information and analyze variables related to research. The instrument in this study used interview sheets and voice recording devices for the data collection process.

\section{RESULTS AND DISCUSSION}

According to the National Population and Family Planning Agency (BKKBN), the range of adolescents is 10-24 years old and not yet married. The subjects in this study were young women in the working area of Jetis I Public Health Center Bantul
Yogyakarta as many as 12 teenagers with 18 years of age as many as five teenagers with student status, 19 years as many as three teenagers with student status, and aged 20 years as many as four teenagers with student status.

Eleven (11) out of Twelve (12) young women responded that pregnant women prevented stunting, and 7 out of 12 young women have the knowledge that stunting is a low body condition. According to respondents, stunting is a state of someone who has growth disorders so that his body is short or also called dwarf or not optimal growth or slow growth.

Respondent A: "In my opinion, Stunting is a growth disorder which can also be a height growth that is physical growth from a person who is due to a lack of nutrients used to help the growth process".

Respondent B: "I think Stunting is like a dwarf, imperfect growth. So the growth is slow, causing stunted children.

Respondent C: Stunting is a condition where the growth of the child is not working as it should or is not optimal such as stunted body growth".

The results of the interviews show the perceptions of young women about improving stunting can be done trough:

1. Stunting prevention measures are carried out by providing counseling, 
especially to pregnant women, especially in rural areas, because the level of knowledge is still low.

2. The first stunting prevention effort is made when the baby is in the mother's womb.

3. To avoid stunting, babies and toddlers must eat nutritious foods.

4. Newborns baby should be given ASI so as not to stunting.

5. Prevention of stunting is done when you want to get married, which must be healthy.

It can be concluded that some female subjects already understood the definition of stunting but did not yet know the critical role of adolescents in the prevention of stunting before pregnancy. This shows that there is no appropriate perception among adolescents regarding the prevention of stunting with a healthy lifestyle since early adolescence. Poor nutritional conditions in adolescents will affect the development of adolescent girls. Adolescent girls are at risk of having less than ideal body weight. There needs to be awareness to increase ideal body weight in adolescents to minimize future stunting events (Mikki et al., 2009; Sumpeno, 2019). Prevention of stunting before pregnancy is to ensure that the nutritional status of the prospective mother is good, does not have anemia, and does not have an infectious disease. That is because the formation of organs occurs during eight weeks of pregnancy, where usually the mother is not aware if she is pregnant, so it would be better if nutrition is improved before pregnancy occurs. The nutritional status of good mothers or cannot be checked through the size of the arm circumference. If the size of the circumference of the prospective mother's arm is less than $23 \mathrm{~cm}$, it means that the prospective mother has a chronic energy shortage (KEK), which is bad for the baby to be conceived later.

Teenagers are the most effective age to get to know the Stunting case. Because when someone already has an insight related to Stunting at the age of getting married, they will be able to anticipate the occurrence of Stunting starting from 0-1000 days of life (HPK). Adolescent girls' readiness in anticipating Stunting as the frontline of prevention can accumulate nutrition fulfillment for the next day. This is the following interview with a nutrition consultant at Gadjah Mada Health Center:

One of the triggers of Stunting is also anemia in young women. Our young women have very high anemias. Have you ever checked Hb? Menstruation and body image. This body image, I feel like I'm fat even though I'm thin 
because I'm not as thin as a Korean artist, for example. So starting young women, we have to eat nutritious foods, not anemia, good nutritional status. So whenever she marries, whenever she is pregnant, she will give birth to a better generation.

Teenagers are at the forefront of the Stunting prevention process. Teenagers are prone to anemia, which is triggered by menstruation and body image. Early preparation to prevent stunting in adolescence can increase the likelihood of the birth of youth or a better generation. On the other hand, data that supports the number of pregnant women in their teens are from the National Socio-Economic Survey data in 2017. The data states that women aged 15-49 years are known that $54.01 \%$ first time pregnant at the age of 20 years (ideal age of pregnancy). The remaining $23.79 \%$ first time pregnant at the age of $19-20$ years, $15.99 \%$ at the age of $17-18$ years, and $6.21 \%$ at the age of 16 years and under. This shows that half of the women who have been pregnant in Indonesia experience their first pregnancy at a young or teenage (Buletin Jendela Data dan Informasi Kesehatan, 2018). Where in general young women who are pregnant at this age have a high risk of giving birth to babies with Low Birth Weight (LBW). LBW alone affects about
$20 \%$ of stunting (Rahayu et al., 2017). According to research by Latifah and Anggraeni, 2013 shows that pregnancy in adolescence is associated with prematurity, low birth weight, and asphyxia. Maternal health and nutritional conditions before and during pregnancy and after delivery affect fetal growth and risk of stunting.

The condition of the mother before pregnancy, both body posture (weight and height) and nutrition is one of the factors that influence the occurrence of stunting. Adolescent girls, as future mothers, should have good nutritional status. Nutrition interventions are needed to reduce stunting cases (Fikadu et al., 2014; Pearson et al., 2018). In 2017, the percentage of young women with short and concise conditions increased from the previous year, which was $7.9 \%$ very short and $27.6 \%$ short (Buletin Jendela Data dan Informasi Kesehatan, 2018). This is supported because not all adolescents monitor or regularly weigh, even though some teenagers have consumed various foods (Sudirman and Jahari, 2012).

Young women who have had insights from the start regarding stunting will get corrective steps if their nutritional status does not currently meet dietary adequacy 
rates. One example of an effort to improve the condition of the body to prevent stunting is to look at the state of the upper arm circumference in young women, according to the quote from the nutritionist's statement as follows:

Your arm circumference is not yet 23.5 $\mathrm{cm}$ ? So you are advised to pay attention to your diet and healthy life. Required upper arm circumference is eligible to prevent the risk of stunting.

For young women, the prevention of Stunting is not only related to fulfilling nutrition. To prevent stunting, it is also necessary to apply Clean and Healthy Lifestyle (PHBS), physical activities that will improve the body's metabolism in absorbing nutrients, routine checks, and prevention of infectious diseases and infections. This is in line with research by Ray et al., 2013 which states that in addition to attention to anthropometric assessments of a population, stunting prevention must be directed towards socioeconomic conditions, nutritious eating patterns, hygiene, and sanitation as well as adequate drinking water. The period before pregnancy, during pregnancy, childbirth, and the period after birth, the implementation of contraception services, as well as sexual health services, states that the factors that aggravate the condition of pregnant women are due to age too young, too old, too often giving birth, and also close birth spacing. Expectant mothers who are too young (under 20 years) are at risk of giving birth to babies with Low Birth Weight (LBW). LBW infants affect about $20 \%$ of stunting (Buletin Jendela Data dan Informasi Kesehatan, 2018). Especially in children in families with several 5 to 8 children, the risk of stunting will increase by 1.3 times compared to children in families with children of 1 to 4 children (Darteh, 2014). Following the facts on the ground, many young women still think that prevention of stunting is carried out in early pregnancy. This makes them believe that it is not the time for them to be aware of the possibility of stunting their children later. The maximum prevention of stunting is as a teenager. The assumption that stunting prevention can only be done when the pregnancy period will cause delays in stunting prevention. When they have been wary of Stunting from the age of marriage, they will maintain their nutritional adequacy to cope with stunting (Warta Kesmas, 2018).

According to Regulation of the Minister of Health No. 97 of 2014 concerning Health Services The existence of policies and programs to overcome the problem of stunting needs to consider various other sectors including water, sanitation and hygiene interventions, household income 
indexes, body mass index, previous birth intervals and facilities to reach information so that they are formed the right perception related to prevention of stunting early on. This is in line with research by Takele, 2019, and Torlesse, 2016 which mentions the determinants of stunted child growth or stunting due to age, gender, body mass index, education on internet facilities, and environmental sanitation. An important factor in preventing stunting is preparing the health of adolescent girls early on by giving them knowledge as soon as possible about stunting. Girls' perceptions and awareness about stunting prevention will significantly affect their health and future stunting prevention.

\section{CONCLUSION}

There is an incomplete and precise perception regarding stunting prevention, potentially making adolescent behavior patterns less prioritizing the health of adolescents. On the other hand, the proportion of teenage pregnancies is higher found in rural rather than urban areas. Half of the women who have been pregnant in Indonesia experience the first pregnancy at a young age or teenager. In terms of nutritional intake, $32 \%$ of girls in Indonesia in 2017 are at risk of a lack of energy chronic. If the adolescent is not repaired, so in the future, there will be more and more expectant mothers who have short body posture and / or lack of chronic energy. This will have an impact on the increasing prevalence of stunting. With the perception of preventing stunting through a clean and healthy life can minimize infectious diseases in adolescents. It is expected that young women can pay attention to health to avoid malnutrition, anemia, and infectious diseases. It's time for teens to play a role in preventing stunting and applying healthy living.

The urgency of providing insights on stunting prevention to young women as an effort to reduce stunting rates in Bantul Regency. By providing insight on stunting, it is expected that teenagers' perceptions can be precise about stunting prevention carried out early on, namely when adolescence. Further research on Stunting is needed so that it can be more comprehensive.

\section{REFERENCE}

Creswell, W John. 2011. Design Pendekatan Kualitatif, Kuantitatif, dan Mixed. Edisi Ketiga. Yogyakarta: Pustaka Pelajar.

Dinas Kesehatan Daerah Istimewa Yogyakarta. 2018. Stunting Tak Sekadar Masalah Tinggi Badan. 14 Desember 2018. Available from: 
https://www.jogjaprov.go.id/berita/d etail/stunting-tak-sekedar-masalahtinggi-badan

Direktorat Gizi Masyarakat. 2018. Buku Saku Pemantauan Status Gizi Tahun 2017. Jakarta: Direktorat Jenderal Kesehatan Masyarakat Kementrian Kesehatan Republik Indonesia

Darteh et al. 2014. Correlates of stunting among children in Ghana. BMC Public Health 14:504. http://www.biomedcentral.com/1471 $-2458 / 14 / 504$

Fikadu et al. 2014. Factors associated with stunting among children of age 24 to 59 months in Meskan district, Gurage Zone, South Ethiopia: a casecontrol study. BMC Public Health. 14:800.

http://www.biomedcentral.com/1471 $-2458 / 14 / 800$

Kementrian Kesehatan Republik Indonesia. 2018. Warta Kesmas. Vol.2

http://www.kesmas.kemkes.go.id/ass ets/upload/dir_519d41d8cd98f00/file s/Warta-Kesmas-Edisi-022018_1136.pdf

Kementrian RI. 2014. Peraturan Menteri Kesehatan Nomor 97 Tahun 2014 tentang Pelayanan Kesehatan Masa sebelum Hamil, Masa Hamil, Persalinan, dan Masa sesudah Melahirkan, Penyelenggaraan Pelayanan Kontrasepsi, serta Pelayanan Kesehatan Seksual. Available from:kesga.kemkes.go.id

Latifah, Lutfatul dan Anggraeni, M Dwi. 2013. Hubugan Kehamilan Pada Usia Remaja Dengan Kejadian Prematuritas, Berat Bayi Lahir Rendah dan Asfiksia. Jurnal Kesmasindo. 6(1): 26-34.
Mikki Nahed, Rahim Abdul HF, Awartani Faisal, and Ottesen GH. 2009. Prevalence and sociodemographic correlates of stunting, underweight, and overweight among Palestinian school adolescents (13-15 years) in two major governorates in the West Bank. BMC Public Health. 9:485. http://www.biomedcentral.com/1471 $-2458 / 9 / 485$

Pearson et al. 2018. Correction to: Optima nutrition: an allocative efficiency tool to reduce childhood stunting by better targeting of nutrition-related interventions. BMC Public Health 18:555. https://doi.org/10.1186/s12889-0185409

Rahayu Warti, Sari D Permata, dan Setianingsih. 2017. Pengaruh Kehamilan Remaja Terhadap Bayi Berat Badan Lahir Rendah. Jurnal SMART Keperawatan. 4(2) www.stikesyahoedsmg.ac.id/ojs/inde x.php/sjkp(perawat)

RRI. 2019. Perkawinan Usia Dini di DIY Meningkat. Available from: http://rri.co.id/yogyakarta/post/berita/ 697094/sosial/perkawinan_usia_dini _di_diy_meningkat.html

Sudiman, Herman dan Jahari, Abas Basuni. 2012. Pengetahuan, Sikap Dan Perilaku Remaja Tentang Keluarga Sadar Gizi (Kadarzi). Media Litbang Kesehatan. 22(2)

Sugiyono. 2014. Memahami Penelitian Kualitatif: Dilengkapi Contoh Proposal dan Laporan Penelitian. Bandung: Alfabeta.

Sumpeno, Wahjudin. 2019. Modul Pelatihan Konvergensi Program Percepatan Pencegahan Stunting. 
Panduan Pelatihan untuk Pelaku di Tingkat Kabupaten/Kota.

Takele et al. 2019. Understanding correlates of child stunting in Ethiopia using generalized linear mixed models. BMC Public Health 19:626.

https://doi.org/10.1186/s12889-019-

6984-x

Tim Redaksi Pusat Data dan Informasi. 2018. Buletin Jendela Data dan Informasi Kesehatan. Topik Utama: Situasi Balita Pendek (Stunting) di Indonesia. Cegah Stunting Itu Penting. Semester I, Tahun 2018. Jakarta: Pusat Data dan Informasi Kesehatan, Kementrian Kesehatan RI. Available from: www.kemkes.go.id, download , buletin > Buletin-Stunting-2018

Torlesse et al. 2016. Determinants of stunting in Indonesian children: evidence from a cross-sectional survey indicate a prominent role for the water, sanitation, and hygiene sector in stunting reduction. $B M C$ Public Health. 16:669. DOI 10.1186/s12889-016-3339-8

World Health Organization (WHO). 2019. Stunting in a nutshell. Available from:

https://www.who.int/nutrition/health ygrowthproj_stunted_videos/en/

World Health Organization (WHO). 2018. Joint child malnutrition estimates. Available from: http://apps.who.int/gho/tableaupublic/tpc-frame.jsp?id=402

World Health Organization (WHO). 2019. World Health Statistics data visualizations dashboard. Available from: https://apps.who.int/gho/data/node.sd

$\mathrm{g}$ 